\title{
Eleven Pack
}

National Cancer Institute

\section{Source}

National Cancer Institute. Eleven Pack. NCI Thesaurus. Code C78774.

A product containing eleven individual units. 